\title{
Analysis of Facts Underlying Judge's Verdict in Resolving Dispute of Value Added Tax on Insurance Discounts and Sale of Repossessed Goods at Finance Company (Study of Tax Dispute Management Perspective)
}

\author{
Indra Himawan Adlan ${ }^{1}$, Christine Tjen ${ }^{1 *}$ \\ ${ }^{1}$ Faculty Economics and Business, Universitas Indonesia, Depok, 16424, Indonesia \\ *christine71@ui.ac.id
}

\begin{abstract}
Value Added Tax (VAT) is a tax which is determined by objective laws to which they are levied. In the process of the collection, often based on a difference in the interpretation of legal provisions between the taxpayer and the tax authorities that led to a tax dispute. One example is the imposition of VAT on transaction receipts insurance discounts and sale of repossessed goods at a finance company. In the Tax Court decision and the Supreme Court have been settled from 2009 to 2013 related to two transactions, almost 100\% decided to grant the request wholly taxpayer Appeal and furthermore rejected the Reconsideration filed by the Directorate General of Taxation. In this study, will be analyzed matters concerning the consideration of the judge in deciding the case of the VAT on the two matters, namely the receipts of insurance discounts and also the sale of repossessed goods. OJK's Circular related insurance discounts and management of tax disputes that DGT would do also be analyzed to formulate effective treatment solutions to the recurring disputes. Receipts of insurance discounts in the context of consumer financing and sale of repossessed goods in the context of the leasing are subjected to VAT. OJK's Circular had no effect on the tax correction for independent tax rules. Several articles in the VAT law and policy rules should also be revised due cause confusion and would need the establishment of new rules specifically for finance company's intermediary services.
\end{abstract}

Keywords: Tax Dispute; Insurance Discount; Repossessed Good.

\section{INTRODUCTION}

According to the law around taxation, tax liability calculations require full self-assessment in Indonesia ${ }^{1}$. This means that tax calculations are subject to various interpretations, both from taxpayers and the Directorate General of Taxation as tax collector. For Value Added Tax (VAT), a debate exists as to whether the transaction of properties including goods/services subject to tax exemption should be imposed. Debate also exists around the interpretation of the law regarding the fundamentals of the tax base and tax rate.

In this case, companies engaged in the field of finance are often faced with tax audits related to VAT on the provision of insurance discounts received from the insurance company partner of the assets purchased by the customer. This is coupled with tax audits related to VAT on goods that are withdrawn. In the case of receipt of insurance discounts, the taxpayer may argue that a discount received as relief is given by the insurer, such that the insurance company functions in this case as the taxpayer. Taxpayers deny that the financial business performed is included in insurance brokerage services. As a result, discounts received are not subject to VAT.

However, tax authorities have variously argued that the money received is not categorized as a discount but commission, since the insured assets are owned by the customer. These assets are therefore categorized as a cash commission under the law relating to VAT and luxury sales tax of taxable services. The economic substance of such disputes should be more emphasized over the formal shape of each transaction or facts of business ${ }^{2}$. Denial by the taxpayer of involvement in a transaction and the execution of their own bookkeeping and VAT tax return completion can be proved through accounting done by each party.

Under Indonesian law, pace civil law, the principle of precedent in jurisprudence is difficult to implement. It is therefore possible that tax authorities apply such precedents with equal gravity ${ }^{3}$. Consideration and implementation by tax authorities may change in view of a case if there is a rule change or the addition of more specific regulations. In the practice of granting insurance discounts today, the Financial Services Authority Circular No. 21 / SEOJK.05 / 2015 does not specifically regulate the granting of discounts and insurance commissions, so that the directly insured individual or policyholder may receive compensation or a premium discount in any form from an insurance company. This can be used against basic income tax authorities to correct the discount regarded as commission subject to VAT.

However, the Financial Services Authority Circular No. 21/SEOJK.05/2015 which regulates the granting of commissions and/or discounts on insurance against several parties (including finance companies) does not 
comprise legal product legislation in Law Number 12 Year 2011 on the Establishment Regulation Legislation ${ }^{4}$. This gives rise to polemics. The Circular is i

$\mathrm{n}$ fact a policy instrument without a legal basis in legislation, as has been pointed out ${ }^{4}$. The policy rules can thus bind the public indirectly. The number of recurrent cases brought by the tax authorities resulted in a significant increase in cases filed 2003 to $2013^{5}$. The fundamental weakness in the interpretation of tax regulations and the immature considerations of both inspectors and investigators provokes considerable objection. These weaknesses have an impact not only on the DGT from the administration, but also from the perspective of the taxpayer concerned with the cost of compliance.

The DGT may undertake a dispute management so that the number of court cases can be minimized and dispute settlements can be quicker and more efficient ${ }^{5,6}$. Improvements are still needed to avoid the uncertainty of tax revenue.

This study will analyze matters concerning judicial considerations around VAT on the two cases that are often repeated in tax court, namely the granting of insurance discounts and the sale of withdrawn goods in finance companies. Further exploration will be conducted that focuses on the substance of transactions and accounting records of the parties engaged in these transactions, based on the prevalence of the transaction and the current rules. In addition, the study will examine the issuance of regulations beyond tax laws such as the Circular of the FSA, which has been expressly regulating the granting of discounts in the FSA Circular Letter No. 06 / D.05 / 2013 and has been repealed and replaced by the FSA Circular Letter No. 21 / SEOJK.05 / 2015. To close the paper, we will construct a comprehensive analysis of the DGT in order to implement more efficient dispute management and to be fair to all interested parties, in order to minimize recurrent tax disputes.

\section{LITERATURE REVIEW}

Value added tax is a procedure for tax collection rather than a kind of tax in itself. In this sense, VAT illustrates a collection system via sales tax levied on the value added. Nonetheless, the focus of the practice of imposing VAT in Indonesia is on the consumption of goods and/or services according to the explanation of VAT $\mathrm{Law}^{7}$.

The legal characters of $\mathrm{VAT}^{8}$, are as follows: (a) VAT is an indirect tax whereby the position of the person in charge of tax payments (sellers) differs from that of the bearer of the tax burden (the buyer); (b) VAT is an objective tax whose payable time is determined by the presence of objects or transactions required under the tax provisions subject to VAT; (c) VAT is a multi-stage non-cumulative levy, but VAT is charged on every chain of production lines and distribution lines with cumulatively imposed taxes on the value added of goods and/or services; (d) the calculation of VAT is to be paid to the state treasury using an indirect reduction method in which the VAT paid is calculated by subtracting the VAT levied at the time of sale with the VAT paid on acquisition of goods or services; (e) VAT is a tax on consumption in the country in which the boundary area where VAT is payable only exists around the customs area, and the destination principle of VAT in Indonesia means that goods or services over cross-country delivery are subject to VAT in the destination country where goods or services are consumed; (f) the VAT Law in Indonesia applies to a single rate of $10 \%$.

\section{Insurance Discount}

One regulation relating to insurance brokerage business is contained in article 9, paragraph 1 of Law No. 2 of 1992 on Insurance Business, where it is stated that all parties who conduct insurance business shall obtain a business license from the Minister, except for companies that organize a Social Insurance Program. Types of insurance business are stated in Article 3, letter B of the law, including insurance brokerage business as a supporting business of insurance companies.

Article 19, paragraph 2 of Government Regulation No. 73 of 1992 on Insurance Business Conduct states 'In the policy or document which is united with it, shall be published details of the portion of premium that is forwarded to the insurance company and part of the premium paid to the Insurance Broker'. The Directorate General of Taxation subsequently issued Circular No. SE-06 / PJ.53 / 1993 for the alignment of understanding among tax officials, stating that insurance brokerage business is not insurance business because it does not bear insurance risk.

Based on the VAT Law amended by Act No. 16 of 2000 on article 4, paragraph 3 and Government Regulation No. 144 of 2000 on Types of Service exempted from VAT, it should be mentioned that services in the fields of banking, insurance, and leasing with option rights are not subjected to VAT unless the insurance broker service is subject to VAT. Before the establishment of the Financial Services Authority, arrangements granting insurance discounts in the Ministry of Finance Regulation No. 74 / PMK.010 / 2007 Article 4 paragraph 2 and paragraph 3 stated that the General Insurance Company may charge an acquisition fee in addition to Commission in the form of discounts, bonuses, gifts, or other benefits to the insurance broker, insurance agent, policyholders, or other third parties associated with the acquisition of the business. In Article 4, clause 1 PMK it is described that is that the commission only is entitled to an insurance agent or broker for brokerage services in the motor vehicle 
insurance business.

The FSA described in Circular Letter No. 06 / SEOJK.06 / 2013 states that insurance discounts can only be granted to the insured directly listed on the insurance policy. However, on June 30, 2015, the Circular was revoked owing to the passing of the FSA Circular Letter No. 21 / SEOJK.05 / 2015, where an extension to the provision of discounts was provided, such that they can also be given to the insured, including the directly insured as well as insurance agents, insurance brokers, and finance companies.

\section{Sale of Withdrawn Goods}

Based on qualitative interviews, it has been stated that the imposition of VAT on the sale of goods withdrawn relies on a binding agreement between parties ${ }^{9}$. Withdrawn goods comprise items withdrawn for their default from the customer/debtor to repay their obligations, so that the assets are returned to the lessor and sold in an auction mechanism or leased back to the other party. Lease financing is a service that is not subject to VAT as is described in Article 4A paragraph 3 of the VAT Law. The same applies to consumer financing, including services that are not subjected to VAT based on the SE-34 / PJ.53 / 1995 on consumer finance, credit card and debit card.

If the goods recorded are fixed assets then it is exposed to Article 16D and if they are not recorded as fixed assets, they are exposed to Article 4, Paragraph 1 of the VAT Act. Second hand vehicles and their tax bases can use any other value. This is based on asset sales traction not being a supply of goods included in the negative list of Article 4A Paragraph 2 of the VAT Law.

\section{RESEARCH METHOD}

This study uses a qualitative approach as an inductive model to gain a deep understanding of a problem, and to generate an interpretation that can answer that problem ${ }^{10}$. A qualitative approach is a research process that generates descriptive data in the form written or verbal texts given by the people being observed ${ }^{11}$.

Data processing begins by making a summary of any decision, either on appeal or judicial review, which relates to the granting of insurance discounts and the sale of goods withdrawn faced by finance companies from the Indonesian Tax Court Secretary website and putusan.mahkamahagung.go.id. Interviews with informants are used to confirm these facts, deepen understanding of the problem, and supplement information to create a comprehensive conclusion.

Limitations associated with this paper include (1) Decisions examined are limited to tax disputes with finance companies as tax payers, excluding claims; (2) Disputes selected are associated with the Tax Base (DPP) on VAT granting of discounts and/or commissions, insurance, and the sale of goods withdrawn. No other disputes relating to material aspects of tax outside are included in the determination of tariffs; (3) The decisions in the Appeal and Judicial Review used by the authors was terminated over the course of the fiscal years from 2009 to 2013; (4) Scheme Leases with Option Rights as the basis of the analysis is limited in terms of the type of Direct Finance Lease, with the goods assumed to have originated from suppliers.

\section{RESULTS AND DISCUSSION}

In ascertaining the law and judicial response to decide a dispute, as stated clearly in Article 78 of the Tax Court Law, a judge may cling onto three areas that form the legal basis, (1) assessment of evidence; (2) the provisions of the legislation, especially regarding taxation; and (3) the judge's own confidence. In the case of an insurance scheme discount in a finance lease, the judge found that: (a) the item is the sole property of the lessor; (b) there is no transfer of ownership from the lessor to the lessee until the option is executed; (c) the inclusion of QQ (qualitate qua) in the policy; (d) no insurance broker services occurred that are subjected to VAT. In the consumer financing schemes, the judge found: (a) the inclusion of QQ in the policy; (B) the finance company is the bearer of risks; (c) brokerage/insurance intermediaries must obtain permission from the Minister of Finance, and finance companies are not entitled to obtain the permit; and (d) no insurance broker services occur that are subjected to VAT. In case the goods are withdrawn, the scheme occurs only within consumer financing. Thus, the judge found that: (a) the buyer is the owner of the goods, not the finance company; (b) there is no transfer of rights when the withdrawal of the defaulting debtor occurs; (c) there is a power of attorney to sell and establish fiduciary agreements; (d) the input tax cannot be credited by the finance company when it purchases from suppliers; and (e) the company does not act as a merchant or dealer of the financed object.

The difference in discounts and insurance commissions can be seen in Table 1. As concerns the substance of transactions with the insurance scheme discount in the direct finance lease, the difference is entitled to the lessor as an income where the lessor's concerns for the insured as property rights exist for the lessor, even while mastery of the financing objects exist on the lessee. In consumer finance transactions, property rights are contained at consumer as debtor. Financing companies act as a liaison between consumers and insurance companies, so these transactions should have been subjected to VAT. Accounting entries made by the financing company at the time not only record the commissions and/or discounts, but there are also finance companies that recognize two things 
accepted as revenue. On the side of insurance companies, the commission is put in charge of the acquisition and stated in the insurance policy. Discounts may be recorded as acquisition costs or directly reduced premiums receivable (net-off).

The connection with the transaction of goods withdrawn is presented in Table 2. The sale of goods is withdrawn from consumer financing schemes. Transition fiduciary property rights that are tied to the initial financing agreement do not function as the transfer of property rights in the sale and purchase of the engagement. The submission does not include delivery of taxable goods subjected to VAT as referred to in Article 4 paragraph 1, letter a of VAT Law or Article 16D VAT Law, although most existing finance companies record withdrawn goods as a corporate asset. In the scheme of the direct finance lease, there are no transfer property rights when the object is withdrawn in terms of lessee default. This way, the sale of withdrawn goods to the other party should be subject to VAT in accordance with Article 4 VAT Law, in case the company does not recognize the object as a fixed asset or Article 16D VAT law, if companies recognize and record the object as fixed assets.

Table.1. Difference between Insurance Discount and Insurance Commission

\begin{tabular}{ll}
\hline Insurance Discount \\
\hline Beneficiary & 1. Payer of insurance premiums (view of tax authorities) \\
2. Policyholder (PMK 74 / PMK.010 / 2007) \\
3. Insured Direct (FSA SE 06 / D.05 / 2013, which has been \\
repealed \\
4. All interested parties in the insurance the insured either \\
directly or intermediary (FSA SE $21 /$ SEOJK.05 / 2015 \\
replaced the FSA SE 06 / D.05 / 2013)
\end{tabular}

Finance Company Accounting Entries
1. When the service is rendered

D: Financing receivable 100

C: Sales 100

When receiving the payment from customer

D: Cash 110

C: Financing receivable 100

Insurance premium liab. 8

Discount revenue 2

\section{Insurance Commission}

1. Financing Company (SE-06 / PJ.53 / 1993; SE FSA 06 / D.05 /

2013 as it has been replaced by the FSA SE 21 / SEOJK.05 /

2015)

2. Insurance Broker or Insurance Agent who obtain permission

Finance minister or registered Financial Services Authority

(PMK 74 / PMK.010 / 2007; Law No. 40 Year 2014; Regulation

63 of 1999; FSA SE 21 / SEOJK.05 / 2015)

3. Bank (FSA SE 21 / SEOJK.05 / 2015)

4. All interested parties in the insurance the insured either

directly or intermediary (FSA SE 21 / SEOJK.05 / 2015)

1. When the service is rendered (commission granted at payment from customer is received)

D: Financing receivable 100

C: Sales 100

When receiving the payment from customer

D: Cash 110

C: Financing receivable 100

Insurance premium liab. 8

Commission 2

2. When receiving payment from the consumer / lessee

(commission is given periodically)

D: Cash 110

C: Financing receivable 100 Insurance premium liab 10

Commission recognition

D: Commission receivable $\mathrm{xxx}$

$\mathrm{C}$ : Commission fee $\mathrm{xxx}$

Recognize expense based on the PMK 74 / PMK.010 / 2007

Directly reducing accounts receivable and insurance premium income (net-off) or recognize expense based on the PMK 74 PMK.010 / 2007

Related to the restitution

Accounting Entries

Time of VAT

recognition

Tax Legal Basis

Article 4A VAT Law, Regulation 144 of 2000 as had been repealed and replaced by Regulation No. 1 Year 2012 in which insurance services are services which are not subjected to VAT.
Over insurance intermediary services provided

Article 4A VAT Law, Regulation 144 of 2000 as had been repealed and replaced by Regulation No. 1 of 2012 in which the brokerage services are not excluded from the delivery of services which were not subjected to VAT

SE-FSA No. 06 / D.05 / 2013 states explicitly that discounts can only be obtainable by the directly insured, and finance companies are only entitled to insurance commission. Policy rules were later changed to FSA Circular Number 21 / SEOJK.05 / 2015 where these limits disappear. However, the Circular outside tax provisions will not be used by judges in deciding a dispute over the tax base, because it does not have binding legal force on the outside $^{4}$. The Directorate General of Taxation follows taxation laws only with implementing regulations.

The management of tax disputes carried out by the Directorate General of Taxation is with the purpose of revising regulations that cause confusion, and interpretations differ significantly between the perpetrators of the tax and the prevention of corrections in the future related to the transaction receipts of insurance discounts in the scheme of finance leasing and the sale of goods withdrawn in consumer financing schemes. The revised regulation needs to be carried out, but with the condition that using regulations has a binding legal to be considered by the Judges as a government regulation, as well as by the Regulation of the Minister of Finance, and the Director General of Taxes.

\section{CONCLUSION}

From the judge's consideration, it was found that there was no consideration of the policy rule because it has no binding legal status ${ }^{13}$. In exchanges for discounts, the right of ownership still resides with the lessor and 
finance companies into directly insured parties in the insurance policy. The transaction is therefore not subject to VAT according to the judicial decision. In the sale of goods that are withdrawn, there is no transfer of property rights when the withdrawal occurs, so that goods still belong to the consumer in consumer financing schemes.

Table.2. The Treatment of Difference of Withdrawn Goods Subjected to VAT Based Transaction Scheme

\begin{tabular}{|c|c|}
\hline & Direct Finance Lease \\
\hline $\begin{array}{l}\text { Ownership by legal } \\
\text { basis }\end{array}$ & $\begin{array}{l}\text { Lessor, as long as the lease agreement with } \\
\text { option rights are still valid and unused option } \\
\text { rights. }\end{array}$ \\
\hline Utilization and / or & Lessee (leasing transactions), unless the event \\
\hline $\begin{array}{l}\text { Economical Control of } \\
\text { Goods }\end{array}$ & of default would occur withdrawal by the lessor \\
\hline $\begin{array}{l}\text { Commercial accounting } \\
\text { based on FAS }\end{array}$ & $\begin{array}{l}\text { The object of financing is recognized as an } \\
\text { asset and depreciated by Lessee (SFAS 30) }\end{array}$ \\
\hline Fiscal reconciliation & $\begin{array}{l}\text { Recognized as an asset by the lessee. } \\
\text { Both lessor and lessee cannot depreciate; }\end{array}$ \\
\hline Legal Standing & $\begin{array}{l}\text { KMK } 1169 \text { / KMK.01 / 1991; KMK } 448 \text { / } \\
\text { KMK.017 / 2000; PMK } 84 \text { / PMK.012 / 2006; } \\
\text { Presidential Decree No. } 9 \text { of 2009; FSA } \\
\text { Regulation No. 29 / POJK.05 / 2014; }\end{array}$ \\
\hline Withdrawal of Goods & $\begin{array}{l}\text { Option rights can be exercised after the value of } \\
\text { the loss and the rest of the debt was repaid by } \\
\text { the lessee in accordance with the principal lease } \\
\text { agreement. }\end{array}$ \\
\hline $\begin{array}{ll}\text { Accounting } & \text { for } \\
\text { withdrawn goods } & \end{array}$ & $\begin{array}{l}\text { Acknowledging back the item as an asset, can } \\
\text { be as inventory or fixed assets }\end{array}$ \\
\hline $\begin{array}{l}\text { Object status of the } \\
\text { current VAT sales of } \\
\text { goods withdrawn by the } \\
\text { tax provisions }\end{array}$ & $\begin{array}{l}\text { Not an taxable object unless the lessor's input } \\
\text { tax are entitled to credit based on Article } 4 \\
\text { paragraph } 1 \text { of the Law of VAT if the company } \\
\text { recognizes the withdrawn goods as assets and / } \\
\text { or for self-use. If the finance company record } \\
\text { and / or utilizing items such as withdrawn } \\
\text { assets, thus that are subjected to VAT Article } \\
\text { 16D when it was sold to a third party }\end{array}$ \\
\hline
\end{tabular}
Consumer Financing
Consumer. There is no partial right for finance companies over the ownership of the collateral goods according to the Law Fiduciary. Finance company is only entitled to limited guarantee of debts and not on the ownership of goods except when the debtor defaults ${ }^{12}$.
Consumers (Debtor), unless the event of default would occur withdrawal by lenders that finance companies

Financing object is recognized as an asset and depreciated by the consumer in terms of consumers is a company that performs bookkeeping (SFAS 16)

Not specifically regulated so that consumers who keep books can depreciate fiscally to reduce income tax

KMK 448 / KMK.017 / 2000; PMK 84 / PMK.012 / 2006; Presidential Decree No. 9 of 2009; FSA Regulation No. 29 / POJK.05 / 2014

If the financing agreement is followed by a fiduciary guarantee agreement, the finance company must sell the items to cut losses due to customer's default.

There are those who recorded as assets.

There are those who did not recognize items as assets

No, because it is clear that this submission is related to the guarantee of debts which the finance company must sell goods that are withdrawn as required by law to do so in an effort to cut loss of the customer's default.

The impact of the FSA Circular on the Judge's Consideration is negligible, since the FSA Circular Letter No. 21 / SEOJK.05 / 2015 only affects terms of business transactions and has no effect on taxation aspects. The causes of this recurring tax dispute is the difference in interpretations of the law and corrections made DGT often do not have a clear legal standing, which is externally binding. In other words, the DGT continues to maintain the status quo and does not seek to change circumstances by adapting rules for business development. Matters relating to the management of tax disputes that can be done by DGT are as follows [1] Revise Explanation of Article 1A, paragraph 1 letter b VAT law so that it limits confusion in its collision with a juridical construction of finance lease transaction. [2] Revise the DGT Circular Letter No. 129 / PJ / 2010 regarding the right to input tax credits in finance lease transactions, which are not currently in line with the juridical construction of finance lease. [3] Propose the establishment of a new rule or revise Ministry of Finance Regulation No. 84 / PMK.012 / 2006 or Regulation of the Financial Services Authority No. 29 / POJK.05 / 2014 to include provisions explicitly governing intermediary services as services that can be conducted by financing companies. [4] Establish Circular Letter to harmonize understandings of related transactions that should be subjected to VAT, in accordance with financing schemes as previously describes. [5] Revise or create new regulations using rules that have a strong external tie, and a strong legal position as laws, government regulations, and/or tenets of the Finance Ministry.

\section{REFERENCES}

[1] Waluyo. Akuntansi Pajak, Penerbit Salemba Empat, Jakarta (2008).

[2] Gunadi. Akuntansi Pajak, Grasindo, Jakarta (2009).

[3] A. D. Harjanti. Kekuatan mengikat dalam yurisprudensi sengketa pajak. Online Article Ministry of Finance Training Center Publication, (2015).

[4] I. Zuraida. Kedudukan peraturan kebijakan (surat edaran, instruksi, petunjuk teknis) dalam hukum positif di Indonesia. Indonesia Ministry of Finance Training Center Publication, (2014).

[5] D. A. Pranoto. Alternative solutions to reduce tax dispute in Indonesia’s tax court. Master Degree Thesis, Universitas Indonesia (2014).

[6] S. Araki, I. Claus. A comparative analysis of tax administration in Asia and The Pacific. Open Access Repository: Asian Development Bank (2014)

[7] U. Sukardji. Pokok-pokok pajak PPN (Ed. Kesepuluh), PT RajaGrafindo Persada, Jakarta (2014).

[8] U. Sukardji. Undang-Undang PPN 1984 setelah perubahan ketiga dengan Undang-Undang Nomor 42 Tahun 2009 komentar pasal demi pasal, PT RajaGrafindo Persada, Jakarta (2010).

[9] H. Prabowo. Perlakuan PPN atas penjualan barang yang ditarik kembali oleh perusahaan pembiayaan. Undergraduate Thesis, Universitas Indonesia (2009).

[10] J. W. Creswell. Research design 3rd edition, SAGE Publications Asia-Pacific Pte. Ltd, Singapore (2009).

[11] L. Moleung. Metodologi penelitian kualitatif edisi 28, PT Remaja Rosdakarya, Bandung (2010).

[12] T. Kamelo. Hukum jaminan fidusia, Alumni, Bandung (2004).

[13] Darussalam, D. Septriadi. Membatasi kekuasaan untuk mengenakan pajak, PT. Grasindo, Jakarta (2009). 